\title{
Ingestive behavior of steers finished on soybean hull and/or white oat grain
}

\section{Comportamento ingestivo de novilhos terminados com casca do grão de soja e/ou grão de aveia branca}

\author{
Álisson Marian Callegaro ${ }^{*}$ (D) , Ivan Luiz Brondani' (D) , Dari Celestino Alves Filho' (D) , \\ Luiz Ângelo Damian Pizzuti' (D), Ricardo Lima Azevedo Júnior' (D), Diego Soares \\ Machado' ${ }^{10}$, Lucas Braido Pereira' ${ }^{10}$, Daniele Borchate ${ }^{10}$, Amanda Farias de \\ Moura'(iD)
}

${ }^{1}$ Universidade Federal de Santa Maria, Santa Maria, RS, Brazil.

*Correspondent - mcalisson@hotmail.com

\section{Section: Zootecnia \\ Received \\ July 13, 2019 \\ Accepted \\ September 16, 2019 \\ Published \\ February 5, 2020}

www.revistas.ufg.br/vet visit the website to get the how to cite in the article page

\begin{abstract}
The objective of this research was to measure the ingestive behavior of steers finished exclusively with concentrate containing soybean hulls (ground) and/or white oat grain. We used 32 steers with Charolais or Nellore predominance. The animals were randomly distributed in the treatments, blocked according to genetic predominance, and allocated in individual pens. Diets were isonitrogenous, being the treatments: Soybean hulls; White oat grain or the Mixture (equal parts), plus limestone and protein nucleus. Steers that received the diet based on soybean hulls remained more time in idle compared to the ones that received the mixture, and these remained more time in idle than the steers that received the diet based on white oat grain. Steers that received the diet based on soybean hulls ruminated less time than the steers fed the mixture, and these less time than those fed white oat grain. Exclusively concentrate diets based on soybean hulls although presenting high soluble fiber content in neutral detergent, are not sufficient to promote an appropriate ingestive behavior of steers of Charolais or Nelore racial predominance.
\end{abstract}

Key words: Effective fiber; High grain diet; Neutral detergent fiber; Rumination

\footnotetext{
Resumo

O objetivo desta pesquisa foi mensurar o comportamento ingestivo de novilhos terminados exclusivamente com concentrado contendo casca do grão de soja (moída) e/ ou grão de aveia branca. Foram utilizados 32 novilhos, com predominâncias raciais Charolês ou Nelore. Os animais foram distribuídos ao acaso nos tratamentos, bloqueados conforme predominância genética e alocados em baias individuais. As dietas foram isonitrogenadas, sendo os tratamentos: Casca do grão de soja; Grão de aveia branca e a Mistura (partes iguais), acrescidos de calcário calcítico e núcleo proteico. Os animais que receberam dieta à base de casca de soja permaneceram mais tempo em ócio, comparados aos que
} 
receberam a mistura; estes, por sua vez, permaneceram mais tempo em ócio em relação aos que tiveram acesso à dieta à base de aveia branca. Os novilhos que consumiram dieta à base de casca de soja ruminaram menos tempo que os da mistura e estes, por sua vez, menos tempo que os novilhos alimentados à base de aveia branca. Dietas exclusivamente com concentrado à base de casca de soja, embora apresentem elevado teor de fibra solúvel em detergente neutro, não são suficientes para promover adequado comportamento ingestivo de novilhos de predominância racial Charolês ou Nelore.

Palavras-chave: Dieta alto grão; Fibra efetiva; Fibra em detergente neutro; Ruminação

\section{Introduction}

Measurement of ingestive behavior is a tool that preserves animal welfare and assists in nutritional management to improve the efficiency and productive performance of animals without economic losses. The ingestive etiology of ruminants consists of three basic activities: feeding, rumination, and idleness.

Ruminants seek to adapt their feed intake to their nutritional requirements. According to Van Soest ${ }^{(1)}$, animals spend approximately one hour eating energy foods and six hours daily for low energy diets. In this sense, the proportion of concentrate in the diet may interfere with the amount of ingested food and hence, ingestive behavior. According to Missio et al. (2), as the proportion of concentrate in the diet increases, there is a decrease in the time spent feeding. These also observed an inverse correlation $(r=-0.77)$ between the concentrate level in the diet and time spent on feed intake.

The advent of agriculture expansion and, consequently, the decrease of livestock areas were factors that eventually led to an intensification of beef cattle and the implementation of new techniques, such as the increased proportion of concentrate in the diet of beef cattle. This technique is characterized by the low proportion of long fibers, leading to the low content of physically effective neutral detergent fiber, being its intake highly correlated with rumination time and ruminal $\mathrm{pH}^{(3)}$.

Moreover, it is the possibility of using soybean hull and white oat grain, which have high availability in most of Brazil and the South region, respectively. These foods have bromatological characteristics that allow their use in the ruminant diet.

Although soybean hull has a high neutral detergent fiber content, some of its fibrous fraction is pectin, which gives it high digestibility ${ }^{(4)}$. Therefore, it can replace high-quality roughages such as corn and sorghum silage. White oat grain can be used in the high-grain diet of ruminants due to its satisfactory nutritional composition ${ }^{(5)}$, not compromising animal performance, as it has a high content of physically neutral detergent fiber, which is responsible for stimulating chewing.

Therefore, the objective of the present research was to measure the ingestive behavior 
of steers finished exclusively on concentrate based on soybean hull and/or white oat grain.

\section{Material and methods}

The experiment was carried out in the Laboratory of Beef Cattle of the Department of Animal Science of the Federal University of Santa Maria (UFSM), located in the Central Depression of the state of Rio Grande do Sul. Thirty-two Charolais or Nellore steers, with an average age and weight of 20 months and $275.09 \mathrm{~kg}$ of live weight at the beginning of the experimental period, respectively, from the herd of the Laboratory of Beef Cattle of UFSM, were used. The study was approved by the Committee on Ethics in the Use of Animals of UFSM (Protocol No. 066/2012(2)).

Animal finishing was carried out in a covered feedlot with 12 square meters, paved boxes, provided with feeders for food supply and troughs with water ad libitum, regulated with a float tap. Treatments were randomized, with one animal per box, distributed according to genetic predominance and initial weight. The animals were adapted to the facilities and diets for 16 days before the experimental period, during which the control of endoparasites was performed with subcutaneous application of albendazole sulfoxide-based product ( $10 \%$ concentration) at the dose recommended by the manufacturer.

The diet was calculated according to $\mathrm{NRC}^{(6)}$ by estimating a dry matter intake (DM) of $2.54 \mathrm{~kg} / 100 \mathrm{~kg}$ live weight (LW) and establishing an isonitrogenous diet (Table 1), as the following treatments: soybean hull - concentrate containing ground soybean hull as a base; white oat grain - concentrate containing white oat grain as a base; and mixture - concentrate containing, in equal parts, soybean hull and white oat grain (Table 1). Calcitic limestone plus protein core was added to all treatments.

During the experimental period, the animals were fed twice a day, in the morning at $8: 30 \mathrm{~h}$ and in the afternoon at $14 \mathrm{~h}$. Protein core and calcitic limestone were supplied in the feeder on the base ingredient to be tested, and homogenization was performed soon after. Daily, before the first supply, the leftovers of the last day were collected, and the value registered in a spreadsheet for the calculation of dry matter and neutral detergent fiber intake. Food supply was pre-established between 50 and $100 \mathrm{~g} / \mathrm{kg}$ higher than voluntary intake and regulated according to animal intake on the previous day.

Samples of ingredients of diets and leftovers were taken twice a week, being well homogenized for better sampling. These samples were pre-dried in a forced air oven at a temperature of $55^{\circ} \mathrm{C}$ for 72 hours, ground in a Willey mill with a $1 \mathrm{~mm}$ opening sieve, and placed in plastic packaging for further laboratory analysis.

Behavior data collection occurred during the experimental period (109 days). They were distributed in four moments, two days for each one. Observations of ingestive behavior consisted of registering the information of daily time spent feeding, ruminating, and idling, standing, or lying down on the left or right side, taken every five minutes by trained observers. 
Table 1. Proportion of ingredients (natural matter) and bromatological composition (dry matter) of diets

\begin{tabular}{lccc}
\hline Ingredients, & \multicolumn{3}{c}{ Treatments } \\
\cline { 2 - 4 } g/kg concentrate (natural & Soybean hull & Mixture & White oat grain \\
\cline { 2 - 4 } matter) & - & 418.0 & 840.0 \\
\hline White oat grain & 834.0 & 418.0 & - \\
Soybean hull & 41.0 & 47.0 & 52.0 \\
Calcitic limestone & 125.0 & 117.0 & 108.0 \\
Protein core & Bromatological composition. g/kg dry matter \\
\hline & 901.18 & 906.49 & 911.75 \\
\hline Dry matter, g/kg natural matter & 154.35 & 154.32 & 154.16 \\
Crude protein & 13.48 & 31.12 & 48.73 \\
Ethereal extract & 103.56 & 101.83 & 98.90 \\
Mineral matter & 407.64 & 278.09 & 149.63 \\
Acid detergent fiber & 593.80 & 424.63 & 256.93 \\
Neutral detergent fiber & 5.11 & 2.97 & 0.86 \\
ADIN & 9.57 & 6.88 & 4.21 \\
NDIN & 186.16 & 146.54 & 107.30 \\
Hemicellulose & 355.11 & 221.15 & 88.22 \\
Cellulose & 20.10 & 30.80 & 41.40 \\
Lignin & 612.11 & 662.89 & 724.16 \\
Total digestible nutrients & 781.65 & 724.34 & 668.54 \\
IVDOM & &
\end{tabular}

A/NDIN = acid/neutral detergent insoluble nitrogen; IVDOM = in vitro digestible organic matter after $72 \mathrm{~h}$ of incubation

The behavior was observed for 48 consecutive hours, and at night, the facilities were maintained with artificial lighting. The number of rumination chews per bolus (NRCB) and time spent on rumination chewing per bolus (TRCB) were obtained by observations per animal in each evaluation period. A digital timer was used to record TRCB. Ingestive behavior data were interpreted according to Bürger et al. ${ }^{(7)}$, as follows: DMRE = DMI/ TRT, NDFRE = NDFI/TRT, TCT = FT + TRT; NBOLUS = TRT $/$ TRCB, NRCD = NRCB $\times N B O L U S$, $T I T=I T S+I T L$, and TRT = RTS + RTL, where DMRE is the dry matter rumination efficiency (g DM/h), DMl is the dry matter intake (g DM/day), TRT is the total rumination time (h/ day), NDFRE is the neutral detergent fiber rumination efficiency (g NDF/h), NDFI is the neutral detergent fiber intake (g NDF/day), TCT is the total chewing time (h/day), FT is the total feeding time (h/day), NBOLUS is the number of boluses chewed per day (no./ day), TRCB is the time spent on rumination chewing per bolus (sec/bolus), NRCD is the number of rumination chews per day (no./day), NRCB is the number of rumination chews per bolus (no./bolus), TIT is the total idling time (h/day), ITS is idling time spent standing (h/day), ITL is the idling time spent lying down on the left or right side (h/day), RTS is the rumination time while standing (h/day), and RTL is the rumination time while lying down on the left or right side.

The experimental design was a randomized block design (racial predominance), with 2020, Cienc. anim. bras., v.21, e-59477 
three treatments and a variable number of samples per treatment, totaling 11 animals in the adaptation period, while 10 and 11 animals were used in the experimental period respectively for treatments with soybean hull and white oat grain and mixture. The animal was the experimental unit. One animal stopped eating during the experimental period and died.

The analyzed data of each experimental unit correspond to the means of evaluations of each animal on the days of ingestive behavior data collection. Variables were tested for normality by the Kolmogorov-Smirnov test. The data were subjected to analysis of variance and F-test by PROC MIXED, and the criterion for choosing the best covariance structure was AIC. The means were compared by the t-test at $5 \%$ significance when differences were detected between them. The mathematical model of analysis of variance corresponds to the general linear model:

$Y i j=\mu+\tau i+\beta j+(\tau i \times \beta j)+\varepsilon i j$

By the model, Yij represents the dependent variables, $\mu$ is the mean of all observations, ti corresponds to the effect of treatments, $\beta \mathrm{j}$ corresponds to the effect of racial predominance, $\tau i \times \beta j$ corresponds to the effect of the interaction between treatment

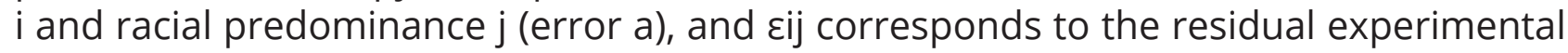
error.

Pearson's correlation test was also performed by the PROC CORR procedure.

The data of the presence of animals at the feeder were analyzed using a completely randomized design, with a $3 \times 24$ factorial ( 3 treatments and 24 hours), according to the following mathematical model:

$Y i j=\mu+\tau i+\omega j+(\tau i \times \omega j)+\varepsilon i j$

Where Yij represents the dependent variables, $\mu$ is the mean of all observations, $\tau i$ corresponds to the effect of treatments, wj corresponds to the effect of hours, $\tau i \times$ $\omega j$ corresponds to the effect of the interaction between treatment $i$ and time $j$, and हij corresponds to the residual experimental error. The data were analyzed using the statistical package $\operatorname{SAS}^{(8)}$.

\section{Results and discussion}

Steers belonging to treatment soybean hull spent more time ingesting food than animals that received the mixture, which, in turn, spent more time than animals that received white oat grain $(\mathrm{P}<0.05$; Table 2$)$. This result is a consequence of the specific density $\left(\mathrm{kg}\left(\mathrm{m}^{3}\right)^{-1}\right)$ of the soybean hull ingredient (Table 1), which provided the lowest bite rate.

Steers that consumed soybean hull-based diet showed shorter $(\mathrm{P}<0.05)$ total rumination time $(69 \mathrm{~min})$ than animals of the mixture treatment $(217 \mathrm{~min})$, which were shorter than animals that consumed white oat grain (343 min). These values represent less than $25 \%$ of the time of day involved with this activity. In this sense, Missio et al. ${ }^{(2)}$ 
found values of $37.33,37.16,30.26$, and $25.50 \%$ of the time of day of steers involved with rumination, receiving diets with $78,60,41$, and $21 \%$ of roughage and $22,40,59$, and $79 \%$ of concentrate, respectively, while Neumann et al. ${ }^{(9)}$ observed $37 \%$ for a diet containing $55 \%$ of concentrate and $45 \%$ of oat hay. Therefore, diets with roughage in their composition tend to require longer rumination time.

Table 2. Behavioral activities of steers fed diets exclusively with concentrate in the feedlot

\begin{tabular}{|c|c|c|c|c|}
\hline \multirow{2}{*}{ Activity, minutes } & \multicolumn{3}{|c|}{ Treatment } & \multirow{2}{*}{$\mathbf{P}$} \\
\hline & Soybean hull & Mixture & White oat grain & \\
\hline Feeding time & $207.18 \pm 8.50 a$ & $159.51 \pm 8.01 b$ & $123.07 \pm 8.01 c$ & 0.0001 \\
\hline Total rumination & $69.24 \pm 13.40 c$ & $217.19 \pm 12.58 b$ & $343.80 \pm 12.58 a$ & 0.0001 \\
\hline $\begin{array}{l}\text { Total rumination } \\
\text { while lying down }\end{array}$ & $67.38 \pm 12.89 c$ & $207.45 \pm 12.10 b$ & $301.86 \pm 12.10 a$ & 0.0001 \\
\hline $\begin{array}{l}\text { Rumination while } \\
\text { lying down (right) }\end{array}$ & $23.88 \pm 7.34 b$ & $54.45 \pm 6.88 b$ & $145.72 \pm 6.88 a$ & 0.0001 \\
\hline $\begin{array}{l}\text { Rumination while } \\
\text { lying down (left) }\end{array}$ & $52.71 \pm 9.97 b$ & $138.35 \pm 9.36 a$ & $150.43 \pm 9.36 a$ & 0.0001 \\
\hline $\begin{array}{l}\text { Rumination while } \\
\text { standing }\end{array}$ & $1.90 \pm 4.84 \mathrm{~b}$ & $9.81 \pm 4.54 b$ & $41.97 \pm 4.54 a$ & 0.0003 \\
\hline Total idling time & $1164.01 \pm 18.37 a$ & $1061.61 \pm 17.24 b$ & $971.61 \pm 17.24 \mathrm{c}$ & 0.0001 \\
\hline $\begin{array}{l}\text { Idling time spent } \\
\text { laying down (right) }\end{array}$ & $452.52 \pm 23.93 a$ & $420.38 \pm 22.55 a$ & $302.25 \pm 22.55 b$ & 0.0002 \\
\hline $\begin{array}{l}\text { Idling time spent } \\
\text { laying down (left) }\end{array}$ & $425.97 \pm 17.57 a$ & $375.37 \pm 16.48 b$ & $287.98 \pm 16.48 c$ & 0.0001 \\
\hline $\begin{array}{l}\text { Total idling time } \\
\text { spent laying down }\end{array}$ & $873.53 \pm 34.56 a$ & $797.33 \pm 32.56 a$ & $592.20 \pm 32.56 b$ & 0.0001 \\
\hline $\begin{array}{l}\text { Idling time spent } \\
\text { standing }\end{array}$ & $283.14 \pm 31.22 b$ & $264.90 \pm 29.47 b$ & $382.0 \pm 29.47 a$ & 0.0162 \\
\hline
\end{tabular}

$\mathrm{P}=$ probability / $\mathrm{a}, \mathrm{b}, \mathrm{c}-$ means with significant differences $(\mathrm{P}<0.05)$ have distinct letters in the row

The time spent ruminating is related to the quantity and quality of the consumed diet ${ }^{(10)}$. The shortest total rumination time observed for steers fed diets with soybean hull and mixture is related to their physically effective fiber content because, although they have a high neutral detergent fiber content, the fiber provided by the soybean hull ingredient is not sufficient to promote rumination. This behavior is due to the small particle size presented by the soybean hull ingredient ${ }^{(11)}$. According to NRC ${ }^{(6)}$, the physically effective fiber is calculated according to the percentage of neutral detergent fiber retained in the $1.18 \mathrm{~mm}$ sieve after vertical separation. The absence of particles with this size does not stimulate rumination, bicarbonate production by saliva, which is a buffer ${ }^{(12)}$, establish a biphasic stratification of ruminal content, nor contribute to the formation of a floating layer of large particles called mat over a pool of liquid and small particles ${ }^{(11)}$.

The lack of physically effective fiber in the soybean hull (2\%) is similar to that of ground 
corn grain (high concentrate diets), which has $4.3 \%^{(11)}$. It is the main reason for the shorter total rumination time of cattle fed soybean hull (Table 2).

Another reason that contributes to the behavior of animals of the soybean hull treatment to present the shorter time involved with total rumination activity (lying down on the right and left side) than white oat grain $(P<0.05)$ may be related to the high digestibility of soybean hull. In general, cattle have no preference for chewing on one side or the other, but the cattle opted for the right side in the present study. This fact may be related to the gas tympanism observed during the visual evaluation of ingestive behavior, a consequence of the high concentrate intake and high production of shortchain fatty acids, which reduce rumen $\mathrm{pH}$ and facilitate the development of lactic acid-producing bacteria(3). These observations were confirmed during data collection of ingestive behavior, in which distension of the left paralumbar fossa was observed, a characteristic of tympanism. Cattle from treatments that included the soybean hull ingredient spent most of their time lying down on the left side compared to the right side in order to provide expulsion of air and facilitate eructation.

Physically effective fiber, in addition to stimulating chewing, rumination, and salivation, also triggers ruminal motility, which is important for increasing substrate contact with extracellular enzymes of rumen microorganisms ${ }^{(13)}$. Kononoff(14) described that the lack of long fibers results in the so-called syndrome, which is a failure or decreased rumination, difficulty in eructation, often causing tympanism or bloating, reduced food intake, and depraved appetite.

The physical properties of diets for ruminants are affected by the proportions between roughages and concentrates, type of forage and concentrate, proportions of chopped non-forage fiber sources, particle size, and processing of diet ingredients ${ }^{(11)}$. Non-forage fiber sources are by-products of plants produced by extracting starch, sugar, lipids, or other constituents of non-fibrous values. These by-products may have neutral detergent fiber content similar to coarse forage, as the soybean hull, but particle size is similar to concentrate.

Animals that received a soybean hull-based diet presented longer idle time (1164 min) than steers that received the mixture treatment (1061 min), which, in turn, remained longer in idling than animals that had access to a white oat grain-based diet (971 min) $(P<0.05$; Table 2). This behavior is due to other activities (total feeding time and rumination), as feeding time of animals also had the same behavior as the total idling time, but the time spent ruminating showed an inverse behavior to the previously mentioned variables $(P<0.05)$, with a correlation of -0.45 with feeding time $(P<0.001)$. Carvalho et al. ${ }^{(15)}$ pointed out that animals submitted to high-grain diets have a long time to perform other activities.

Steers submitted to treatments mixture and white oat chewed more times and remained longer chewing the rumen bolus than animals fed soybean hull $(P<0.05)$, with a mean value of 69.08 vs. 42.02 chews and 74.68 vs. 47.05 seconds, respectively (Table $3)$. The time spent on chewing per bolus was highly correlated with the number of chews per bolus ( $r=0.96 ; P<0.0001$ ). Bürger et al. ${ }^{(7)}$ found 51.47 rumination chews per regurgitated bolus per steer fed $90 \%$ concentrate diet. Chewing time has been one of 
the most studied measures to evaluate fiber effectiveness ${ }^{(13)}$. Carvalho et al. ${ }^{(16)}$ observed that rumination and chewing time decreased linearly with the increasing replacement of soybean hull by sorghum silage.

Thus, when the percentage of NDF in the diet is lower than $60 \%$, the residual dietary forage must have sufficient particle size to promote chewing, as most non-forage fiber sources do not stimulate chewing as effectively as long forage ${ }^{(17)}$.

These results confirm the importance of studying fiber effectiveness, as treatments with the highest content of neutral detergent fiber in the diet $(59.38,42.46$, and $25.69 \%$ in soybean hull, mixture, and white oats, respectively) did not provide longer rumination time for steers $(P>0.05)$, demonstrating that neutral detergent fiber is not a parameter to promote rumination.

Intrinsic factors in soybean hulls such as rapid digestion rate and extrinsic factors such as small particle size and specific weight may have contributed to shorter chewing (Table 3) and rumination time (Table 2). However, the larger grain size of whole white oat may have contributed to the longer chewing time of the bolus. Accordingly, almost all of the diet ingredients (protein core and white oat grain) of this treatment had particles larger than $1.2 \mathrm{~mm}$, which are responsible for promoting chewing. According to Berchielli et al. ${ }^{(3)}$, intake of whole grains instead of crushed can increase the time spent on chewing during consumption and rumination. In this context, ruminant animals can reduce the duration of daily chewing time by increasing the efficiency in particle reduction.

Table 3. Rumination activities of steers fed diets exclusively with concentrate in the feedlot

\begin{tabular}{lcccc}
\hline Variable & \multicolumn{3}{c}{ Treatment } & P \\
\cline { 2 - 4 } & Soybean hull & Mixture & White oat grain & \\
\hline $\begin{array}{l}\text { Number of chews per } \\
\text { bolus }\end{array}$ & $42.02 \pm 4.05 \mathrm{~b}$ & $68.70 \pm 3.79 \mathrm{a}$ & $69.46 \pm 3.79 \mathrm{a}$ & 0.0001 \\
$\begin{array}{l}\text { Time spent on } \\
\text { chewing per bolus, }\end{array}$ & $47.05 \pm 4.30 \mathrm{~b}$ & $73.27 \pm 4.04 \mathrm{a}$ & $76.09 \pm 4.04 \mathrm{a}$ & 0.0001 \\
$\begin{array}{l}\text { seconds } \\
\text { Number of }\end{array}$ & & & \\
$\begin{array}{l}\text { ruminated boluses } \\
\text { per day }\end{array}$ & $91.76 \pm 18.51 \mathrm{c}$ & $186.94 \pm 17.30 \mathrm{~b}$ & $282.75 \pm 17.30 \mathrm{a}$ & 0.0001 \\
$\begin{array}{l}\text { Number of chews per } \\
\text { minute }\end{array}$ & $53.30 \pm 1.07$ & $56.37 \pm 1.00$ & $54.95 \pm 1.00$ & 0.1328 \\
$\begin{array}{l}\text { Number of } \\
\text { rumination chews } \\
\text { per day }\end{array}$ & $3896.5 \pm 857 \mathrm{c}$ & $12294.0 \pm 800.42 \mathrm{~b}$ & $18922.0 \pm 800.42 \mathrm{a}$ & 0.0001 \\
\hline \begin{tabular}{l}
$\mathrm{P}=$ probability / $\mathrm{a}, \mathrm{b}, \mathrm{c}-$ means with significant differences $(\mathrm{P}<0.05)$ have distinct letters in the row \\
\hline
\end{tabular}
\end{tabular}

In addition, the soybean hull is characterized by having in vitro digestibility of organic matter similar to that of noble foods such as corn and soybean meal, besides having in its fibrous fraction the pectin, which presents high degradability and contributes for 
high cell wall digestibility compared to the cited foods ${ }^{(18)}$. Cellulose and hemicellulose are also present in the plant cell wall, occupying space in the digestive tract and requiring chewing to reduce particle size and passage through the digestive $\operatorname{tract}^{(3)}$. Although the proportion of hemicellulose in the diet was higher for steers fed the soybean hull treatment, it did not reflect in the chewing activity, probably due to the presence of pectin.

Steers fed diet exclusively with soybean hull-based concentrate regurgitated fewer cakes and hence chewed lower number of boluses per day in relation to animals of the mixture treatment, which, in turn, presented a lower value in relation to animals fed white oat grain $(P<0.05$; Table 3$)$. This result was due to the lower content of physically effective fiber in the soybean hull diet, which promoted less repletion of rumen contents and, consequently, less rumination. This information is supported by the theory mentioned above that soybean hull has a highly digestible fiber, and its smaller particle size may have favored the digestion and passage through rumen-reticulum.

A correlation between feeding time and dry matter intake was expected, but it did not occur ( $P=0.1268)$ because, usually, the longer the feeding time, the higher the feed intake. Dry matter intake ( $\mathrm{kg} /$ day) was not affected by treatments $(P>0.05$; Table 4$)$, with a mean value of $7.87 \mathrm{~kg} /$ day. In contrast, neutral detergent fiber intake had the behavior affected by the bromatological composition of the diet. In this sense, animals fed soybean hull had a neutral detergent fiber intake 22.2 and $113.0 \%$ higher $(P<0.05)$, respectively, in relation to the treatments mixture and white oat grain.

Table 4. Dry matter (DM) and neutral detergent fiber (NDF) intake and rumination efficiency of steers fed diets exclusively with concentrate

\begin{tabular}{|c|c|c|c|c|}
\hline \multirow[b]{2}{*}{ Variable } & \multicolumn{3}{|c|}{ Treatment } & \multirow[b]{2}{*}{$\mathbf{P}$} \\
\hline & Soybean hull & Mixture & $\begin{array}{l}\text { White oat } \\
\text { grain }\end{array}$ & \\
\hline Dry matter intake, kg/day & $7.35 \pm 0.362 a$ & $8.41 \pm 0.341 a$ & $7.87 \pm 0.341 a$ & 0.1231 \\
\hline $\begin{array}{l}\text { Neutral detergent fiber } \\
\text { intake, kg/day }\end{array}$ & $4.90 \pm 0.18 a$ & $4.01 \pm 0.17 b$ & $2.30 \pm 0.17 c$ & 0.0001 \\
\hline $\begin{array}{l}\text { DM rumination efficiency, } \\
\text { g/h }\end{array}$ & $10618 \pm 809 a$ & $2531 \pm 743 b$ & $1448 \pm 743 b$ & 0.0001 \\
\hline $\begin{array}{l}\text { NDF rumination efficiency, } \\
\text { g/h }\end{array}$ & $7137 \pm 529 a$ & $1208 \pm 486 b$ & $428 \pm 486 b$ & 0.0001 \\
\hline
\end{tabular}

In the present study, dry matter intake was positively correlated with neutral detergent fiber intake $(r=0.44 ; P<0.0001)$. Usually the opposite is observed, i.e., diets with higher neutral detergent fiber content provide lower dry matter intake. According to 
Mertens et al.(11), neutral detergent fiber intake above $12 \mathrm{~g}$ per $\mathrm{kg}$ body weight limits dry matter intake. In addition, a strong positive correlation is found between ruminal $\mathrm{pH}$ of forage $(r=0.63)$ or physically effective fiber $(r=0.71)$, indicating that the higher the neutral detergent fiber or physically effective fiber intake, the higher the ruminal $\mathrm{pH}^{(3)}$. This information was not confirmed in the present study because the most fibrous diet (soybean hull), with the highest neutral detergent fiber content (59.38\%), had a ruminal $\mathrm{pH}$ value below 5.6 throughout the day, which is another indication of a lack of physically effective fiber. In this case, the low $\mathrm{pH}$ is due to a high lactic acid production, which exceeds the absorption capacity of the ruminal epithelium ${ }^{(19)}$, which leads to a change in acid-base balance and, hence, to a subacute ruminal acidosis. According to López et al. ${ }^{(20)}$, it is the result of a sharp decrease in $\mathrm{pH}$ from 5.5 to 5.0 and maintained for 111 to 180 minutes for 24 hours. Subacute ruminal acidosis is a common health and production problem occurring in cattle fed low-fiber diets ${ }^{(21)}$.

Diet rumination efficiency, expressed in $g$ DM/h, increased as neutral detergent fiber content increased in the diet $(P<0.0001)$, with the same behavior when expressed in $g$ NDF/h (Table 4). NDF rumination efficiency showed a behavior directly proportional to neutral detergent fiber intake because the higher the content of this fraction, the higher the rumination efficiency $(r=0.35 ; P<0.0001)$. Another factor contributing to this result was a short rumination time of diets with high NDF content $(69.24,217.19$, and 343.80 min for soybean hull, mixture, and white oat grain, respectively). The opposite is usually the case, i.e., diets with high concentrate proportions and, hence, low NDF content, tend to provide high dry matter rumination efficiency and low neutral detergent fiber rumination efficiency ${ }^{(2,7)}$. Thus, as the concentrate fraction increases, the proportion of cellulolytic bacteria decreases, increasing amylolytic bacteria and also the proportion of concentrate in the regurgitated ruminal bolus, with better dry matter rumination efficiency.

Contrary to the literature, the results of the present study show that the high NDF rumination efficiency is related to the intake of cell wall components (hemicellulose and cellulose), which was high for soybean hull, intermediate for the mixture, and low for white oat grain. Although hemicellulose and cellulose need to be chewed for particle size reduction and passage through the digestive tract, they are potentially digestible fractions, allowing the animals to regurgitate fewer bolus, chew fewer times per bolus, and spend less time chewing (Table 3).

Missio et al.(2) investigated decreasing roughage to concentrate ratios in the diet of steers with racial predominance similar to the animals used in the present study. They found DM and NDF rumination efficiency of $1110 \mathrm{~g}$ and $217 \mathrm{~g} /$ hour, respectively, at the highest concentrate level (79\%), with 16.5\% NDF content. These values are closer to those found in the treatment with white oat grain, with a value of $25.69 \%$ NDF. Moreover, Bürger et al. (7) also studied different roughage to concentrate ratios up to the $90 \%$ concentrate level in the diet, and dry matter rumination efficiency increased as concentrate level increased, but NDF rumination efficiency decreased. These authors found 1456.80 and $298.15 \mathrm{~g}$ dry matter and NDF ruminated per hour, respectively, which is in agreement with the white oat grain treatment. 
The analysis of variance of the data of the presence of steers at the feeder showed an interaction between treatment and hour $(P=0.0125)$, and sometimes alternated (Figure 1).

Animals fed soybean hull or mixture at intervals between feedings (8:30 to $14 \mathrm{~h}$ ) were more present at the feeder due to the lower energy content of these diets, which could justify an attempt of high dry matter intake, but this increase was not observed.

As previously mentioned, it was due to the imbalance in the ruminal environment, as the steers had a pH below 5.6 throughout the day. Silva et al.(22) observed that animals tend to fractionate their diet when it interferes with ruminal $\mathrm{pH}$ stability.

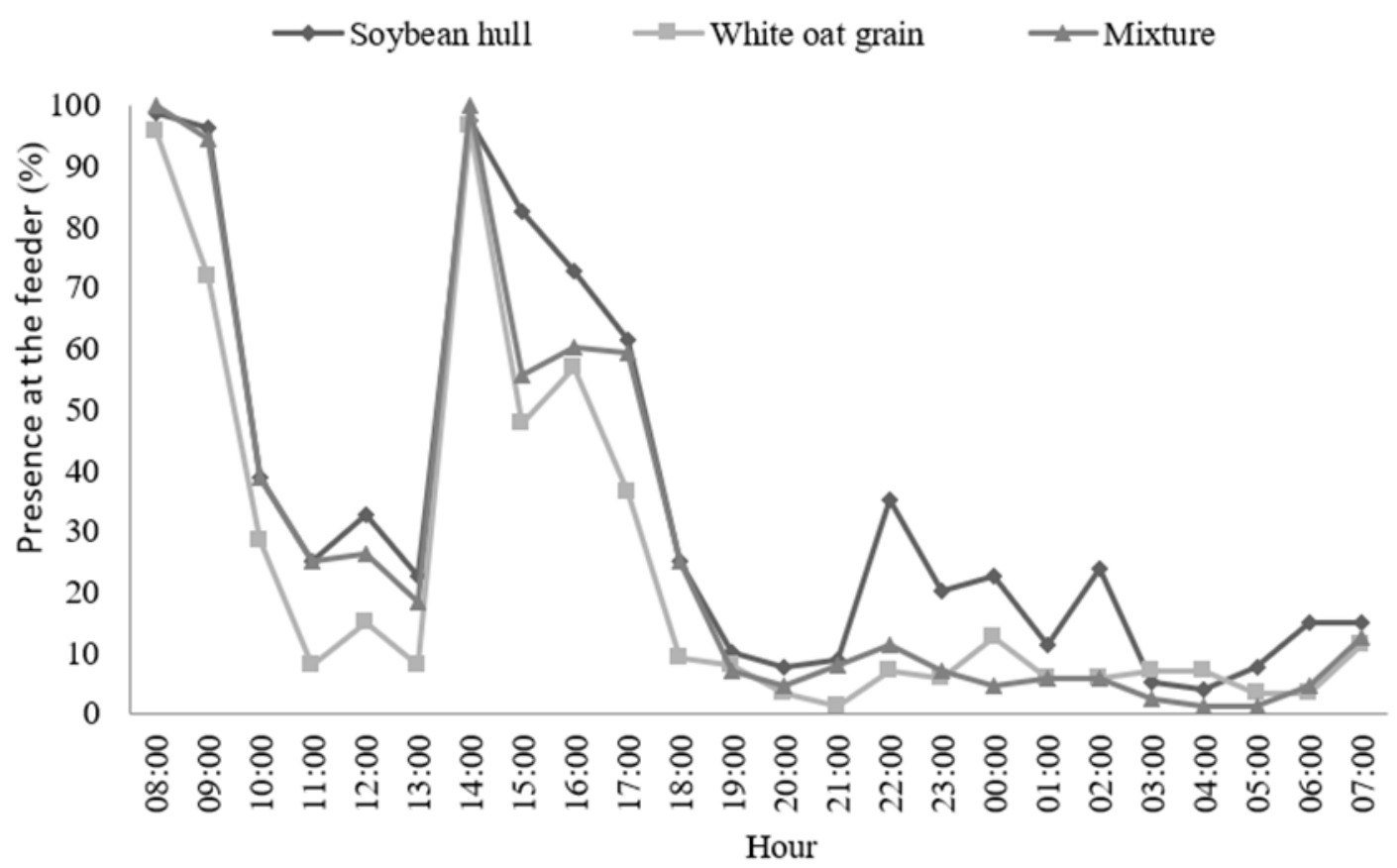

Figure 1 - Presence of steers at the feeder (\%)

In general, almost all animals were present at the feeder when food was available (8:30 and $14 \mathrm{~h}$ ), with no difference between the means of the studied treatments $(P=0.6563)$.

\section{Conclusion}

Diet exclusively with soybean hull-based ingredient has high neutral detergent fiber content but is not sufficient to promote adequate ingestive behavior of feedlot-finished steers.

Diets without a source of white oat grain-based roughage and mixture do not affect the feeding time, rumination, and idling in cattle. 


\section{Acknowledgments}

The authors thank the Beef Cattle Laboratory team of the Department of Animal Science from Federal University of Santa Maria for their dedication to this research.

\section{References}

1. Van Soest PJ. Nutritional ecology of the ruminant. 2 ed. Ithaca, NY, Cornell University Press, 1994. 476p. English.

2. Missio R.L, Brondani IL, Alves Filho DC, Silveira MF, Freitas LSF. Comportamento ingestivo de tourinhos terminados em confinamento, alimentados com diferentes níveis de concentrado na dieta. Revista Brasileira de Zootecnia. 2010;39(7):1571-1578. Avaliable from: http://dx.doi.org/10.1590/S151635982010000700025. Portuguese.

3. Berchielli TT, Pires AV, Oliveira SG. Nutrição de Ruminantes. $2^{\circ}$ Ed. Jaboticabal: Funep; 2011. 616p. Portuguese.

4. Callegaro AM, Alves Filho DC, Pizzuti LÂD, Segabinazzi LR, Brondani IL, Martini APM. Comportamento ingestivo de novilhos mestiços terminados em confinamento alimentados com borra de soja. Ciência Animal Brasileira. 2018;19:1-12. Available from: http://dx.doi.org/10.1590/1809-6891v19e-28150. Portuguese.

5. Bernardes GMC, Carvalho S, Pires CC, Motta JH, Teixeira WS, Borges LI, Fleig M, Pilecco VM, Farinha ET, Venturini RS. Consumo, desempenho e análise econômica da alimentação de cordeiros terminados em confinamento com o uso de dietas de alto grão. Arquivos Brasileiros de Medicina Veterinária e Zootecnia. 2015;67(6):1684-1692. Available from: http://dx.doi.org/10.1590/1678-4162-7934. Portuguese.

6. National Research Council. Nutrient requirements of beef catle. 7 rev. ed., Washington: National Academy Press. 2000. 242p. English.

7. Bürger PJ, Pereira JC, Queiroz AC, Silva JFC, Valadares Filho SC, Cecon PR, Casali ADP. Comportamento ingestivo em bezerros holandeses alimentados com dietas contendo diferentes níveis de concentrado. Revista Brasileira de Zootecnia. 2000;29(1):236-242. Available from: http://dx.doi.org/10.1590/S151635982000000100031. Portuguese.

8. SAS Institute Incorporation. Statistical Analysis System: user guide [CD-ROM]. Version 6. Cary (NC): SAS Insitute Inc., 2001. English.

9. Neumann M, Figueira DN, Ueno RK, Mattos Leão GF, Heker Junior JC. Desempenho, digestibilidade da matéria seca e comportamento ingestivo de novilhos holandeses alimentados com diferentes dietas em confinamento. Semina: Ciências Agrárias. 2015;36(3):1623-1632. Available from: http://dx.doi. org/10.5433/1679-0359.2015v36n3p1623. Portuguese.

10. Mendes CQ, Turino VF, Susin I, Pires AV, Morais JB, Gentil RS. Comportamento ingestivo de cordeiros e digestibilidade dos nutrientes de dietas contendo alta proporção de concentrado e diferentes fontes de fibra em detergente neutro. Revista Brasileira de Zootecnia. 2010;39:594-600. Available from: http:// dx.doi.org/10.1590/S1516-35982010000300019. Portuguese.

11. Mertens DR. Creating a system for meeting the fiber requirements of dairy cows. Journal of Dairy Science, Savoy. 1997; 80(7):1463-1481. English.

12. González LA, Manteca X, Calsamiglia S, Schwartzkopf-Genswein KS, Ferret A. Ruminal acidosis in feedlot 
cattle: Interplay between feed ingredients, rumen function and feeding behavior (a review). Animal Feed Scince and Technology. 2012;172:66-79. Available from: https://doi.org/10.1016/j.anifeedsci.2011.12.009. English

13. Silva MRH, Neumann M. Fibra efetiva e fibra fisicamente efetiva: Conceitos e importância na nutrição de ruminantes. FAZU em Revista. 2012;9:69-84. Available from: http://www.fazu.br/ojs/index.php/ fazuemrevista/article/viewArticle/491. Portuguese.

14. 9. Kononoff PJ. Understanding effective fiber in rations for dairy cattle. Published by university of Nebraska. 2005. Available from: https://digitalcommons.unl.edu/cgi/viewcontent.cgi?referer=https:// www.google.com/\&httpsredir=1\&article=1458\&context=extensionhist. English.

15. Carvalho S, Bernardes GMC, Pires CC, Bianchi G, Pilecco VM, Venturini RS, Motta JH, Teixeira C. Efeito de dietas de alto grão sobre o comportamento ingestivo de cordeiros em confinamento. Zootecnia Tropical. 2015;32(2):145-152. Spanish.

16. Carvalho S, Dias FD, Pires CC, Brutti DD, Lopes JF, Santos D, Barcelos RD, Macari S, Wommer TP, Griebler L. Comportamento ingestivo de cordeiros Texel e Ideal alimentados com casca de soja. Archivos de Zootecnia. 2014;63(241):55-64. Available from: http://dx.doi.org/10.4321/S0004-05922014000100006. Spanish.

17. Grant RJ. Interactions among forages and nonforage fiber sources. Journal of Dairy Science, Savoy. 1997;80(7):1438-1446. Available from: https://doi.org/10.3168/jds.S0022-0302(97)76073-9. English.

18. Zambom MA, Santos GT, Modesto EC, Alcalde CR, Gonçalves GD, Silva DC, Silva KT, Faustino JO. Valor nutricional da casca do grão de soja, farelo de soja, milho moído e farelo de trigo para bovinos. Acta Scientiarum. 2001;23(4):937-943. Available from: http://periodicos.uem.br/ojs/index.php/ActaSciAnimSci/ article/view/2648/0. Portuguese.

19. Dijkstra J, Ellis JL, Kebreab E, Strathe AB, López S, France J, Bannink A. Ruminal pH regulation and nutritional consequences of low pH. Animal Feed Scince and Technology. 2012;172:22-23. Available from: https://doi.org/10.1016/j.anifeedsci.2011.12.005. English.

20. López EJ, Ortiz MFI, Mercado GP, Chavez JMC. Ruminal acidosis: strategies for its control. Austral Journal of Veterinary Sciences. 2017;49:139-148. Available from: http://dx.doi.org/10.4067/S071981322017000300139. English.

21. Zhao $\mathrm{XH}$, Zhang $\mathrm{T}, \mathrm{Xu} \mathrm{M}$, Yaho JH. Effects of physically effective fiber on chewing activity, ruminal fermentation, and digestibility in goats. Journal Dairy Scince. 2011;89:501-509. Available from: https:// doi.org/10.2527/jas.2010-3013. English.

22. Silva VS, Alves Filho DC, Freitas LS, Brondani, IL, Restle J, Azevedo Junior RL, Teixeira, OS. Sources of carbohydrates in the ingestive behavior of feedlot steers. Revista Brasileira de Zootecnia. 2014;43(5):273277. Available from: http://dx.doi.org/10.1590/S1516-35982014000500008. Portuguese. 